\title{
Numerical study of EGR effects on the combustion process parameters in HCCI engines
}

\begin{abstract}
One of the main problems in the HCCI engine is the control and operation of the combustion process. At present the primary method of control of the combustion process in an HCCI engine system is EGR (Exhaust Gas Recirculation). The paper presents the results of three-dimensional modeling of combustion in a single-cylinder HCCI engine powered with $D M E$ fuel with a cooled external EGR. 3D modeling was performed in AVL Fire code. This work investigates the effects of EGR rate on the basic combustion parameters including start of the ignition (SOI), burn duration (BD), indicated pressure ( $p_{i}$ ) and nitric oxide (NO) emissions. The modeling results show that increasing of the EGR rate in HCCI engine can delay the start of ignition (SOI) effectively and leads to a prolongation of the burn duration (BD). Delayed ignition in the HCCI engine through EGR, can provide similar performance $\left(p_{i}\right)$ compared to conventional $C I$ engine and at the same time provide a significant reduction in $\mathrm{NO}_{x}$ emissions.
\end{abstract}

Key words: homogenous charge compression ignition, exhaust gas recirculation, heat release rate

\section{Badania numeryczne wpływu EGR na parametry procesu spalania w silniku HCCI}

Jednym z głównych problemów w silniku HCCI jest sterowanie i kontrola procesu spalania. Obecnie podstawowa metoda kontroli spalania w silniku z systemem HCCI jest EGR (recyrkulacja spalin). W artykule przedstawiono wyniki trójwymiarowego modelowania procesu spalania w jednocylindrowym silniku HCCI zasilanym paliwem DME z chtodzonym zewnętrznym EGR. Modelowanie 3D przeprowadzono w programie AVL Fire. Niniejszy artykut przedstawia badania wpływu stopnia EGR na podstawowe parametry procesu spalania, tj. chwile poczatku zapłonu (SOI), czas trwania spalania (BD), ciśnienie indykowane (p.) i emisję tlenku azotu (NO). Wyniki modelowania wskazują, że zwiększenie EGR w silniku HCCI może skutecznie opóźnić rozpoczęcie zapłonu (SOI) i prowadzić do wydlużenia czasu trwania spalania (BD). Opóźniony zapłon w silniku HCCI przy użyciu EGR umożliwia uzyskanie osiagów (p.) podobnych do osiagów konwencjonalnego silnika ZS i jednocześnie zapewnia znaczna redukcję emisji NO.

Słowa kluczowe: zapłon samoczynny mieszanki jednorodnej, recyrkulacja spalin, szybkość wydzielania ciepta

\section{Introduction}

HCCI (Homogenous Charge Compression Ignition) combustion system is now one of the most promising solutions used in piston engines. It combines the best features of spark ignition engines and compression ignition engines, and is characterized by low $\mathrm{NO}_{\mathrm{x}}$ and $\mathrm{PM}$ emissions and high efficiency. So far conducted research on HCCI engine not solved the problem of control of moment of autoignition of homogeneous mixture supplied to engine and duration of the combustion process. At present the suggested method of control and combustion process in HCCI engine system is the EGR (Exhaust Gas Recirculation). The result of the ERG is to provide, to the supply system and then to the engine's combustion chamber, a certain amount of exhaust gas, which participates in the next cycle in the combustion process.

The presented work concerns the numerical study of the use of cooled external EGR to control the combustion process of homogeneous mixtures in HCCI engine. The effects of EGR rate on the basic combustion parameters including start of the ignition timing (SOI), burn duration (BD), indicated pressure (pi) and nitric oxide (NO) emissions was analyzed. Modeling in the AVL Fire was carried out. The aim of modeling was to show the advantages resulting from the use of cooled external EGR on the HCCI engine. The use of EGR should allow you to control the HCCI combustion

\section{Wstęp}

System spalania HCCI (Homogenous Charge Compression Ignition - zapłon samoczynny mieszanki jednorodnej) jest obecnie jednym z najbardziej korzystnych rozwiązań stosowanych w silnikach tłokowych. Łączy najlepsze cechy silników o zapłonie iskrowym i samoczynnym, a ponadto zapewnia małą emisję $\mathrm{NO}_{\mathrm{x}}$ i PM oraz wysoką sprawność. Pomimo wielu dotychczasowych prac nad silnikami z systemem HCCI, nadal pozostaje nierozwiązany problem kontroli chwili samozapłonu mieszanki jednorodnej doprowadzonej do silnika oraz czasu trwania spalania. Obecnie sugerowaną metodą sterowania i kontroli procesu spalania w silniku z systemem HCCI jest EGR (Exhaust Gas Recirculation - recyrkulacja spalin), polegający na wprowadzaniu do układu zasilania a następnie komory spalania silnika pewnej ilości spalin, która w następnym cyklu pracy ma wziąć udział w procesie spalania.

Niniejszy artykuł dotyczy badań numerycznych nad wykorzystaniem chłodzonego zewnętrznego EGR do sterowania procesem spalania mieszanki jednorodnej w silniku z systemem HCCI. Badano wpływ stopnia EGR na podstawowe parametry procesu spalania, tj. chwilę początku zapłonu (SOI), czas trwania spalania (BD), ciśnienie indykowane $\left(\mathrm{p}_{\mathrm{i}}\right)$ i emisję tlenku azotu (NO). Modelowanie przeprowadzono w programie AVL Fire. Celem modelowania było wskazanie 
process, and should contribute to reduce emissions of $\mathrm{NO}$ in comparison with the conventional compression-ignition engines.

\section{The existing state of research}

Development works on combustion, emissions of harmful exhaust gas components and controlled autoignition in HCCI system and application of the system in a real engine are conducted in many research centers and universities around the world. Work [1] investigates the basic combustion parameters including start of the ignition, burn duration, cycle-to-cycle variation, and carbon monoxide (CO), unburned hydrocarbon (UHC), and nitric oxide ( $\mathrm{NO}_{\mathrm{x}}$ ) emissions of homogeneous charge compression ignition engines fueled with primary reference fuels and their mixtures. Two primary reference fuels, n-heptane and iso-octane, and their blends were evaluated. The experimental results show that, in the first-stage of combustion, the start of ignition is retarded, the maximum heat release rate decreases, and the pressure and temperature rises during the first-stage of combustion decrease with the increase of RON (research octane number). Furthermore, the cumulative heat release in the first-stage of combustion is strongly dependent on the concentration of $\mathrm{n}$-heptane in the mixture. The start of ignition of the secondstage of combustion is linear with the start of ignition of the first-stage. The combustion duration of the second-stage of combustion decreases with the increase of the equivalence ratio (inverse of the excess air coefficient) and the decrease of the octane number. The cycle-to-cycle variation improved with the decrease of the octane number. In [2], which is a continuation of [1], the influence of exhaust gas recirculation (EGR) rate, intake charge temperature, coolant-out temperature, and engine speed on the HCCI combustion characteristics and its emissions were evaluated. The experimental results indicate that the ignition timing of the first-stage of combustion and second-stage of combustion are retarded, and the combustion duration prolongs with the introduction of cooled EGR. At the same time, the HCCI combustion using high cetane number fuels can tolerate a higher EGR rate, but only $45 \%$ EGR rate at $1800 \mathrm{rpm}$. Furthermore, there is a moderate effect of EGR rate on $\mathrm{CO}$ and UHC emissions for HCCI combustion engines fueled with n-heptane, but a distinct effect on the emissions for higher octane number fuels. Moreover, the combustion phase advances, and the combustion duration gets shortened with the increase of intake charge temperature and the coolant temperature, and the decrease of the engine speed. At last, it can be found that the intake charge temperature gives the most sensitive influence on the HCCI combustion characteristics.

Work [3] investigates partial HCCI combustion as a control mechanism for HCCI combustion. The premixed fuel is supplied via a port fuel injection system located in the intake port of a DI diesel engine. Cooled EGR is introduced for the suppression of advanced autoignition of the premixed fuel. The premixed fuels used in this experiment are gasoline, diesel, and n-heptane. The results show that with diesel premixed fuel, a simultaneous decrease of $\mathrm{NO}_{x}$ and soot can be obtained by increasing the premixed ratio. korzyści wynikających z zastosowania chłodzonego zewnętrznego EGR w silniku z systemem HCCI. Zastosowanie EGR ma pozwolić na sterowanie procesem spalania oraz przyczynić się do większego ograniczenia emisji $\mathrm{NO}_{\mathrm{x}}$ niż $\mathrm{w}$ konwencjonalnym silniku o zapłonie samoczynnym.

\section{Dotychczasowy stan badań}

Prace badawczo-rozwojowe nad procesem spalania, emisją szkodliwych składników spalin i kontrolowanym samozapłonem w systemie HCCI oraz aplikacją tego systemu w rzeczywistym silniku są prowadzone w wielu ośrodkach badawczych i akademickich na całym świecie.

W ramach pracy [1] badano podstawowe parametry spalania w silniku HCCI, takie jak: chwilę zapłonu, czas trwania spalania, niepowtarzalność kolejnych cykli pracy silnika, emisję tlenku węgla, emisję niespalonych węglowodorów i tlenków azotu, w silniku zasilanym paliwami odniesionymi do paliwa wzorcowego i ich mieszaninami. Brano pod uwagę dwa rodzaje paliw wzorcowych: n-heptan i izooktan oraz ich mieszaniny. Wyniki badań eksperymentalnych wskazują, że w pierwszym etapie spalania ze wzrostem liczby oktanowej badanego paliwa początek zapłonu mieszanki jest opóźniony, maleje maksymalna szybkość wydzielania ciepła, rośnie ciśnienie i temperatura oraz maleje czas trwania pierwszego etapu spalania. Ponadto skumulowane wydzielanie ciepła $\mathrm{w}$ pierwszym etapie spalania jest silnie uzależnione od stężenia n-heptanu w mieszance. Spowodowanie zapłonu w drugim etapie spalania jest liniowo zależne od początku zapłonu w pierwszym etapie. Czas trwania spalania w drugim etapie maleje ze wzrostem współczynnika ekwiwalencji (odwrotność współczynnika nadmiaru powietrza) i spadkiem liczby oktanowej paliwa. Powtarzalność kolejnych cykli pracy silnika ulega poprawie wraz ze spadkiem liczby oktanowej paliwa.

W pracy [2], będącej kontynuacją [1], badano wpływ recyrkulacji spalin (EGR), temperatury ładunku dolotowego, temperatury płynu chłodzącego i prędkości obrotowej silnika na proces spalania oraz emisję spalin silnika HCCI. Wyniki eksperymentu wskazują, że wprowadzenie chłodzonego EGR wpływa na czas zapłonu w pierwszym etapie procesu spalania i opóźnianie drugiego etapu spalania oraz przedłużenie czasu trwania spalania. Jednocześnie okazało się, że wysoka liczba cetanowa paliwa umożliwia stosowanie dość dużej ilości EGR, nawet do 45\% przy 1800 obr/min. Ponadto istnieje niewielki wpływ stopnia EGR na emisję CO i UHC dla systemu spalania HCCI w silniku zasilanym n-heptanem. Wyraźny wpływ na emisję można zauważyć dopiero dla paliw o większych liczbach oktanowych. Ponadto wyprzedzenie procesu spalania i czas trwania spalania skraca się ze wzrostem temperatury ładunku dolotowego i temperatury płynu chłodzącego oraz spadkiem prędkości obrotowej. W rezultacie okazało się, że temperatura ładunku dolotowego ma największy wpływ na charakter procesu spalania w silniku HCCI.

W pracy [3] przeprowadzono badania częściowego spalania HCCI jako mechanizmu kontroli spalania. Przygotowane paliwo dostarczane było systemem wtrysku znajdującego się w układzie dolotowym silnika Diesel DI. Chłodzony 
However, when the intake charge is heated for the improved vaporization of diesel fuel, higher intake temperature limits the operational range of HCCI combustion due to severe knocking and high $\mathrm{NO}_{x}$ emission at high premixed ratios. Gasoline premixing shows the most significant effects in the reductions of $\mathrm{NO}_{\mathrm{x}}$ and soot emissions, compared to other kinds of premixed fuels.

Paper [4] focuses on the effects of internal and cooled external exhaust gas recirculation on the combustion and emission performance of diesel fuel homogeneous charge compression ignition. The use of fuel injection before the top dead center of an exhaust stroke and the negative valve overlap to form the homogeneous mixture achieves low $\mathrm{NO}_{\mathrm{x}}$ and smoke emissions. Internal and external EGR are combined to control the combustion. Internal exhaust gas recirculation (IEGR) benefits are that it forms a homogeneous mixture and further reduces smoke emission, but lowers the high load limits of HCCI engines. Cooled external EGR can delay the start of combustion (SOC) effectively, which is very useful for high cetane fuel (diesel) HCCI because these fuels can easily self-ignite, making the SOC earlier. External EGR can eliminate knocking of HCCI at high load, which means it can extend the high load limit. HCCI maintains low smoke emission at various EGR rates and various loads compared with a conventional diesel engine because there are no fuel-rich volumes in the cylinder.

In paper [5], by using advanced combustion simulation package SENKIN, both thermal and chemical effects of the hot internal EGR on HCCI combustion were calculated and analyzed. It was found that the thermal energy contained in the EGR is essential for the combustion initiation, but the chemical species it contained have different effects towards both combustion ignition timing and heat release rate. The thermal effect is related to the high temperature of the EGR. It increases the temperature of the entire intake charge, helps the charge to overcome its activation energy and therefore advances the ignition timing. The chemical effect comes from the chemically active species that the EGR contained. The active species decrease the activation energy level of the entire charge, and make the ignition easier.

The thermodynamic and chemical effects of real EGR, simulated EGR, and individual EGR constituents $\left(\mathrm{N}_{2}, \mathrm{CO}_{2}\right.$, and $\mathrm{H}_{2} \mathrm{O}$ ) on the HCCI autoignition processes of ethanol have been investigated experimentally and computationally in paper [6]. The results for ethanol were compared in detail with the existing data for gasoline and iso-octane. The data show that addition of EGR retards time of autoignition while the intake temperature remains constant. However, the amount of retardation is dependent on the specific fuel type, with ethanol showing the lowest sensitivity to the addition of clean simulated EGR gases. The response to EGR can be explained by quantifying the various underlying mechanisms. The results show that the single-stage ignition fuel - ethanol is quite sensitive to the reduction of compression heating that occurs with EGR due to a higher heat capacity of the EGR gases compared to air. This high sensitivity to the cooling effect of EGR is similar to that of gasoline and
EGR jest wprowadzany w celu zapobiegania zbyt wczesnemu samozapłonowi mieszanki palnej. Do eksperymentu przygotowano paliwa: benzynę, olej napędowy i n-heptan. Wyniki wskazują, że zmniejszenie emisji $\mathrm{NO}_{\mathrm{x}} \mathrm{i}$ sadzy silnika może być osiągnięte przez zwiększenie stopnia wymieszania paliwa-oleju napędowego ze spalinami. Jednak wskutek zwiększenia stopnia wymieszania doprowadzony ladunek ulega podgrzaniu i następuje odparowanie oleju napędowego, a wysoka temperatura na dolocie ogranicza zakres pracy spalania HCCI i jest przyczyną wystąpienia stuków i zwiększonej emisji $\mathrm{NO}_{x}$. Najlepsze efekty redukcji $\mathrm{NO}_{x}$ uzyskano dla mieszaniny benzyny.

Praca [4] dotyczy wpływu zastosowania wewnętrznego i chłodzonego zewnętrznego EGR na proces spalania i parametry emisji silnika HCCI zasilanego olejem napędowym. Zastosowanie wtrysku paliwa przed GMP w czasie suwu wydechu i zwiększone pokrycie zaworów prowadzi do powstania homogenicznej mieszaniny oraz osiagnnięcia niskiego poziomu emisji $\mathrm{NO}_{x}$ i dymu dla silnika HCCI. W celu kontroli spalania HCCI połączono wewnętrzny i zewnętrzny EGR. Wewnętrzna recyrkulacja spalin przyczynia się do zhomogenizowania mieszanki i zmniejsza emisję dymu, ale ogranicza możliwość dużego obciążenia silnika HCCI. Chłodzony zewnętrzny EGR może skutecznie opóźnić początek spalania, co jest bardzo przydatne dla paliw o wysokiej liczbie cetanowej, takich jak olej napędowy, ponieważ paliwa te mogą łatwo ulegać samozapłonowi, przyspieszając początek spalania. Zewnętrzny EGR może zapobiegać spalaniu stukowemu w silniku z HCCI przy dużych obciążeniach, a to oznacza możliwość osiągania przez silnik wysokich obciążeń. Stopień EGR w silniku HCCI utrzymuje małą emisję dymu w porównaniu z emisją w konwencjonalnym silnikiem wysokoprężnym, ponieważ w silniku HCCI z EGR nie ma w cylindrze przestrzeni bogatych w paliwo.

W pracy [5], przy użyciu zaawansowanych metod symulacji spalania w pakiecie SENKIN, obliczano i analizowano termiczne i chemiczne skutki działania gorącego wewnętrznego EGR na proces spalania HCCI. Stwierdzono, że energia cieplna pochodząca z EGR jest istotna przy rozpoczęciu zapłonu mieszanki, ale chemiczne składniki EGR wywołują różne skutki zarówno wobec czasu zapłonu procesu spalania, jak i szybkości wydzielania ciepła. Wpływ termiczny EGR jest związany z jego wysoką temperaturą. EGR zwiększa temperaturę całego ładunku dolotowego, pomaga osiągnąć temperaturę aktywacji i dlatego przyspiesza chwilę zapłonu. Wpływ chemiczny pochodzi od aktywnych chemicznie składników zawartych w EGR. Aktywne składniki obniżają poziom energii aktywacji i sprawiają, że zapłon staje się łatwiejszy.

W pracy [6] badano doświadczalnie i obliczeniowo termodynamiczne i chemiczne wpływy zastosowania rzeczywistego EGR, symulowanego EGR, poszczególnych składników EGR $\left(\mathrm{N}_{2}, \mathrm{CO}_{2}\right.$ i $\left.\mathrm{H}_{2} \mathrm{O}\right)$ na procesy samozapłonu etanolu w silniku HCCI. Wyniki dla etanolu były porównywalne ze szczegółowymi danymi uzyskanymi dla benzyny i izooktanu. Dane wskazują, że dodanie EGR opóźnia chwilę 
iso-octane, which also are single-stage ignition fuels under these conditions. On the other hand, ethanol is very insensitive to the reduction of $\mathrm{O}_{2}$ concentration associated with the addition of EGR.

Work [7] investigates the effects of exhaust gas recirculation and operation parameters including engine speed, equivalence ratio, coolant-out temperature, and intake charge temperature on the basic characteristics of a single-cylinder homogeneous charge compression ignition (HCCI) engine powered with reformulated iso-octane fuels. The operating range of iso-octane HCCI engine can be extended to lower temperatures and more load by adding di-tertiary butyl peroxide (DTBP) in the fuel. The combustion timing advances with the increase of DTBP concentrations, coolant temperature and equivalence ratio. The effects of EGR on the combustion and emissions are remarkable when the EGR rate is higher than $25 \%$, and the combustion phase is sharply postponed and the UHC and CO emissions deteriorate. The intake charge temperature has a moderate effect on combustion and emissions when it is lower than $35^{\circ} \mathrm{C}$; but the combustion timing advances, the combustion duration shortens, and sometimes it leads to knock combustion when the intake charge temperature increases to above $35^{\circ} \mathrm{C}$.

The effects of the inert components of EGR gas on reducing of the pressure rise rate of homogeneous charge compression ignition engine combustion were investigated numerically in paper [8] by utilizing the CHEMKIN II package and its SENKIN code, as well as Curran's dimethyl ether reaction scheme. Calculations were conducted under constant volume combustion and engine combustion conditions (one compression and one expansion only, respectively). Results show that with constant fuel amount and initial temperature and pressure, as EGR ratio increases, the combustion times are retarded and the duration of the thermal ignition preparation extends non-linearly; peak values of pressure, pressure rising rate (PRR) and temperature decrease; peak values of heat release rate in both low temperature heat release (LTHR) and high temperature heat release (HTHR), decrease. Moreover, maximum PRR decreases as CA50 (timing when accumulated heat release reaches $50 \%$ of the input fuel heat value) is retarded. With constant fuel amount, mixtures with different EGR ratios can obtain the same CA50 by adjusting the initial temperature. Under the same CA50, as EGR ratio increases, the LTHR timing is advanced and the duration of the thermal ignition preparation is extended. The maximum PRR is almost constant with the fixed CA50 despite the change in the EGR ratio, indicating that the influence of EGR dilution on the chemical reaction rate is offset by other factors.

In this paper, by using the advanced combustion simulation package AVL Fire, effects of the cooled exhaust gas recirculation (EGR) on HCCI combustion were investigated and analyzed numerically. This work investigates the effects of EGR rate on the basic combustion parameters including start of the ignition (SOI), burn duration (BD), indicated pressure $\left(\mathrm{p}_{\mathrm{i}}\right)$ and nitric oxide $\left(\mathrm{NO}_{\mathrm{v}}\right)$ emissions of a single-cylinder HCCI engine powered with dimethylether fuel (DME). samozapłonu, gdy temperatura dolotowa jest utrzymywana na stałym poziomie. Jednak długość opóźnienia jest uzależniona od rodzaju konkretnego paliwa; etanol wykazuje najmniejszą wrażliwość na dodatek symulowanych czystych gazów z EGR.

Reakcja na doprowadzony EGR może być wyjaśniona na podstawie kilku różnych, podstawowych mechanizmów. Wyniki analizy wskazują, że jednostopniowy zapłon etanolu jest bardzo wrażliwy na zmniejszone podgrzewanie podczas sprężania, które występuje przy EGR z powodu większej pojemności cieplnej gazów EGR w porównaniu do powietrza. Tak duża czułość etanolu na efekt chłodzenia EGR jest zbliżona do benzyny i izooktanu, które również w tych warunkach charakteryzują się jednostopniowym zapłonem. Jednak etanol jest bardzo odporny na zmniejszenie stężenia $\mathrm{O}_{2}$ związane $\mathrm{z}$ dodatkiem EGR.

Praca [7] dotyczy wpływu recyrkulacji spalin (EGR) i parametrów pracy, w tym prędkości obrotowej, współczynnika ekwiwalencji, temperatury wyjściowego płynu chłodzącego oraz temperatury ładunku dolotowego na podstawowe cechy jednocylindrowego silnika HCCI zasilanego izooktanem. Zakres pracy silnika HCCI zasilanego izooktanem może być rozszerzony do zakresu niższych temperatur i większych obciążeń przez dodanie do paliwa nadtlenku dwu-trzeciorzędowego butylu (DTBP). Chwila spalania zostaje przyspieszona ze wzrostem stężenia DTBP, temperatury płynu chłodzącego i współczynnika ekwiwalencji. Wpływ recyrkulacji spalin na spalanie i emisję są godne uwagi wtedy, gdy stopień EGR jest wyższy niż 25\%; wtedy etap spalania jest znacznie przesunięty, a emisja UHC i CO ulega pogorszeniu. Gdy temperatura ładunku dolotowego jest niższa niż $35^{\circ} \mathrm{C}$, ma ona nieznaczny wpływ na spalanie i emisję; kiedy wzrasta powyżej $35^{\circ} \mathrm{C}$, przyspieszony zostaje czas spalania i skraca się czas spalania, a czasem prowadzi to do wystąpienia spalania stukowego.

Badania numeryczne wpływu obojętnych składników EGR na ograniczenie szybkości narastania ciśnienia w silniku HCCI, z wykorzystaniem pakietu CHEMKIN II, kodu SENKIN oraz schematu reakcji Currana dimetylu eteru, przeprowadzono w pracy [8]. Obliczenia prowadzono dla stałej objętości spalania i dla warunków silnika spalinowego (odpowiednio dla jednego suwu sprężania i jednego suwu rozprężania). Wyniki pokazują, że przy stałej ilości paliwa, stałej temperaturze i stałym ciśnieniu dolotowym wzrost stopnia EGR powoduje opóźnienie czasu spalania, a czas przygotowania zapłonu nieliniowo się przedłuża; wartości szczytowe ciśnienia, szybkość narastania ciśnienia (PRR) i temperatura maleją; szczytowe wartości szybkości wydzielania ciepła w obu: niskiej (LTHR) i wysokiej (HTHR) temperaturze wydzielania ciepła zmniejszają się. Ponadto maksimum PRR zmniejsza się, gdy czas uwolnienia 50\% całkowitego ciepła zawartego w doprowadzonym paliwie (CA50) opóźnia się. Dzięki regulacji temperatury początkowej przez mieszanie stałej ilości paliwa ze zmieniającą się ilością EGR, można regulować wartością CA50. Dla tego samego CA50, wzrost stopnia EGR powoduje przesunięcie czasu wystąpienia LTHR, a czas trwania termicznego przy- 
Among various alternative fuels, dimethylether (DME) has become a primary candidate to replace diesel fuel because it is estimated that the exhaust emissions from vehicles using DME are significantly lower than the exhaust emissions from vehicles using diesel fuel [9]. From the viewpoint of combustion characteristics, DME fuel can be operated in a diesel cycle and obtains a similar thermal efficiency to diesel fuel owing to its good self-ignitability and high cetane number. DME can be produced from various materials, including natural gas, coal and biomass classified as renewable fuels.

In recent years the numerical modeling investigations using more and more advanced mathematical models have been intensely developing. The development of numerical modeling is reinforced with increasing computational power that allows modeling of not only flow processes but also combustion in 3D [10-15]. One of more advanced numerical models used for combustion process in piston engine modeling is AVL Fire [16]. In 2009 Institute of Internal Combustion Engines and Control Engineering of Czestochowa University of Technology began University Partnership Program with AVL List GmbH Company and to model thermal cycle of IC engines using AVL Fire software [17-23]. The AVL Fire software belongs to contemporary programs which are used for modeling of thermal cycles of internal combustion engines. AVL Fire allows modeling of a flow and thermal processes that occur in the intake manifold, the combustion chamber of IC engines and the exhaust pipe with a catalyst and a particulate filter. This program enables the calculation of transport phenomena, mixing, ignition and turbulent combustion in internal combustion engine. Homogeneous and inhomogeneous combustion mixtures in spark ignition and compression ignition engines can be modeled using this software as well. The kinetics of the chemical reactions phenomena is described by combustion models that take into account the oxidation processes in high temperatures. Several models apply to auto ignition processes including HCCI combustion. AVL Fire allows modeling of knock processes that occur in the combustion chamber of IC engines. This program allows building three-dimensional computational grids, characterizes the boundary conditions of surfaces and initial conditions of simulation. The postprocessor gives a possibility to visualize the results.

\section{Test engine and model assumptions}

Modeling of the thermal cycle of the HCCI engine in the AVL Fire program was carried out. The object of the investigations was a modernized diesel engine $1 \mathrm{hc} 102$ Andoria fueled with DME. As a result of the modernization the shape of the combustion chamber was modified. The compression ratio has not changed and was equal to 17.5. The engine was operated at a constant speed of $1800 \mathrm{rpm}$. The engine is a stationary, two-valve unit with a horizontal cylinder configuration. The cooling system of the engine is the evaporation of the water jacket. Table 1 presents the main engine parameters, initial conditions and Fire sub-models. gotowania zapłonu zostaje wydłużony. Przy stałym CA50 maksymalna wartość PRR była niemal stała, pomimo zmian w ilości EGR, co oznacza, że wpływ rozcieńczenia EGR na szybkość reakcji chemicznych jest niwelowany przez inne, dodatkowe czynniki. W ramach niniejszej pracy, korzystając $\mathrm{z}$ zaawansowanego pakietu symulacji procesu spalania AVL Fire, wykonano obliczenia i dokonano analizy numerycznej wpływu recyrkulacji schłodzonych spalin (EGR) na spalanie HCCI. Przedstawiono w niej wpływ stopnia EGR na podstawowe parametry procesu spalania, tj. chwilę początku zapłonu (SOI), czas trwania spalania (BD), ciśnienie indykowane $\left(\mathrm{p}_{\mathrm{i}}\right)$ i emisję tlenku azotu (NO), jednocylindrowego silnika z samoczynnym zapłonem mieszanki jednorodnej (HCCI) zasilanym paliwem DME (eter dimetylowy).Wśród różnych paliw alternatywnych eter dimetylowy (DME) ma stać się podstawowym kandydatem do zastąpienia oleju napędowego, ponieważ szacuje się, że emisja toksycznych składników dla pojazdów zasilanych DME jest znacznie niższa od emisji pojazdów zasilanych olejem napędowym [9]. Z punktu widzenia charakterystyk spalania paliwo DME może pracować w cyklu Diesla i umożliwia uzyskanie podobnych wartości sprawności cieplnej do oleju napędowego, ze względu na jego dobre właściwości samozapłonu i wysoką liczbę cetanową. DME może być produkowany z różnych materiałów, w tym gazu ziemnego, węgla i biomasy, i może być zaliczony do paliw odnawialnych. W ostatnich latach w modelowaniu numerycznym wykorzystuje się stale udoskonalane i rozwijane modele matematyczne. Rozwój modelowania numerycznego możliwy jest przez zwiększenie mocy obliczeniowej komputerów, która pozwala na modelowanie nie tylko procesów przepływowych, ale także procesu spalania w układzie 3D [10-15]. Jednym z bardziej zaawansowanych modeli numerycznych stosowanych do modelowania procesu spalania $\mathrm{w}$ silnikach jest program AVL Fire [16]. Instytut Maszyn Tłokowych i Techniki Sterowania Politechniki Częstochowskiej od 2009 roku do modelowania obiegu cieplnego silnika tłokowego wykorzystuje program firmy AVL List GmbH - AVL Fire [17-23], w ramach uczestnictwa w University Partnership.

AVL Fire należy do najnowocześniejszych narzędzi wykorzystywanych w modelowaniu obiegu cieplnego tłokowego silnika spalinowego. Program daje możliwość modelowania procesów cieplno-przepływowych, począwszy od układu dolotowego poprzez komorę spalania silnika aż do układu wydechowego z katalizatorem i filtrem cząstek stałych. Program AVL Fire umożliwia obliczanie zjawisk transportu, mieszania, zapłonu i turbulentnego spalania $\mathrm{w}$ silniku tłokowym o spalaniu wewnętrznym. Modelować można spalanie zarówno mieszanek homogenicznych przygotowanych w komorze spalania, jak i mieszanek heterogenicznych utworzonych przez wtrysk paliwa do komory, ponadto obliczenia mogą dotyczyć silnika o zapłonie iskrowym albo silnika wysokoprężnego. W programie tym kinetyka zjawisk chemicznych jest opisana przez modele spalania uwzględniające procesy utleniania $\mathrm{w}$ wysokiej temperaturze. Kilka dostępnych modeli dotyczy analizy samozapłonu paliw węglowodorowych, w tym również 
Table 1. Modeling parameters

Tabela 1. Parametry modelowania

\begin{tabular}{|c|c|}
\hline \multicolumn{2}{|l|}{ Engine parameters/parametry silnika } \\
\hline Type/typ & $\begin{array}{l}\text { Water-cooled, } 4 \text { stroke/chlodzony ciecza, } \\
\text { czterosuwowy }\end{array}$ \\
\hline Number of cylinders/liczba cylindrów & 1 \\
\hline Displacement volume/pojemność skokowa & $918 \mathrm{~cm}^{3}$ \\
\hline Engine speed/prędkość obrotowa & $1800 \mathrm{rpm}$ \\
\hline Bore $x$ stroke/średnica $x$ skok & $100 \times 120 \mathrm{~mm}$ \\
\hline Connecting-rod length/dtugość korbowodu & $216 \mathrm{~mm}$ \\
\hline Squish/niedojście ttoka & $2.5 \mathrm{~mm}$ \\
\hline Compression ratio/stopień sprężania & 17.5:1 \\
\hline Injection timing (conventional engine)/kat wyprzedzenia wtrysku (silnik konwencjonalny) & 10, 8, 6 deg BTDC $/ 10,8,6^{\circ} \mathrm{OWK}$ przed GMP \\
\hline \multicolumn{2}{|l|}{ Initial conditions/warunki poczatkowe } \\
\hline Initial pressure for $180 \mathrm{deg} \mathrm{BTDC} /$ ciśnienie poczatkowe $180^{\circ} \mathrm{OWK}$ przed GMP & $0.9 \mathrm{MPa}$ \\
\hline Initial temperature for 180 deg BTDC/temperatura poczatkowa $180^{\circ} \mathrm{OWK}$ przed GMP & $340 \mathrm{~K}$ \\
\hline Equivalence ratio/wspólczynnik ekwiwalencji & $0.5 ; 0.625$ \\
\hline EGR & $0-60 \%$ \\
\hline Fuel/paliwo & DME - dimethyl ether $\mathrm{CH}_{3} \mathrm{OCH}_{3}$ \\
\hline \multicolumn{2}{|l|}{ AVL Fire sub-models/podmodele } \\
\hline Turbulence model/model turbulencji & k-zeta-f \\
\hline Combustion models/model spalania & $\begin{array}{c}\text { Eddy Breakup Model (conventional engine CI/ } \\
\text { konwencjonalny silnik ZS) } \\
\text { Coherent Flame Model ECFM (HCCI engine) }\end{array}$ \\
\hline Ignition models/model zapłonu & $\begin{array}{c}\text { Diesel (conventional engine } \mathrm{CI} / \text { konwencjonalny } \\
\text { silnik ZS) } \\
\text { HCCI Shell Model (HCCI engine) }\end{array}$ \\
\hline $\mathrm{NO}$ formation model/model tworzenia $\mathrm{NO}$ & Extended Zeldovich Model \\
\hline
\end{tabular}

On the basis of the real dimensions of the experimental engine a three-dimensional mesh of the engine combustion chamber was built (Fig. 1). The mesh of the modeled
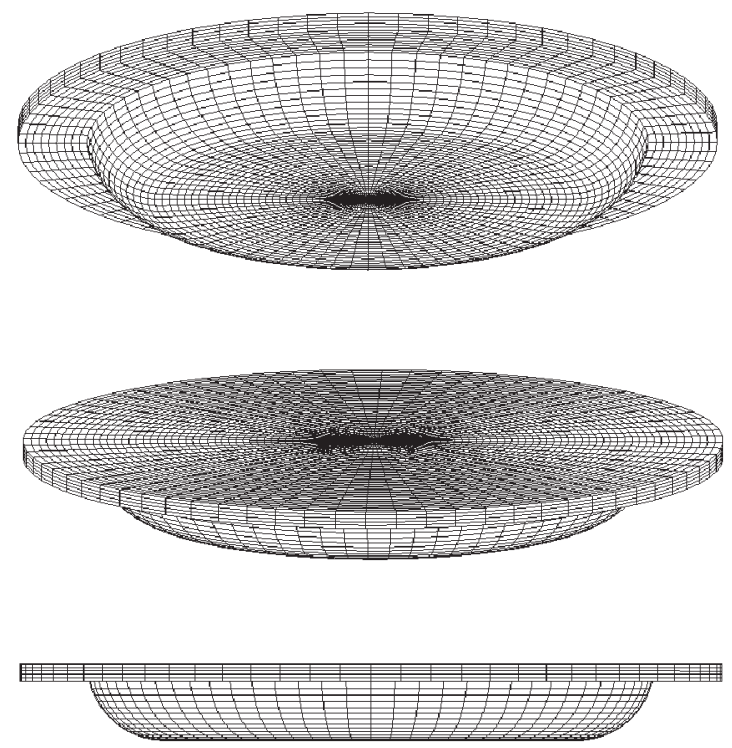

Fig. 1. The computational mesh for combustion chamber of the test engine

Rys. 1. Siatka obliczeniowa komory spalania silnika badawczego spalania typu HCCI. AVL Fire umożliwia modelowanie zjawiska spalania stukowego w komorach silnika tłokowego. Program pozwala na stworzenie trójwymiarowej siatki przestrzeni obliczeniowej, określenie warunków brzegowych poszczególnych powierzchni i warunków początkowych symulacji oraz wizualizację otrzymanych wyników w bogato wyposażonym postprocesorze.

\section{Silnik badawczy i założenia modelu}

Modelowanie cyklu cieplnego silnika HCCI przeprowadzono w programie AVL Fire. Obiektem badań był zmodernizowany silnik Diesla Andoria $1 \mathrm{hc} 102$ zasilany eterem dimetylowym DME. Silnik jest jednostką stacjonarną, dwuzawodową, o poziomym układzie cylindra. W silniku zastosowano system chłodzenia przez odparowanie płaszcza wodnego. W wyniku modernizacji zmieniono kształt komory spalania. Stopień sprężania nie uległ zmianie i wynosił 17,5. Silnik pracował przy stałej prędkości $1800 \mathrm{obr} / \mathrm{min}$. W tabeli 1 przedstawiono podstawowe parametry silnika, warunki początkowe i podmodele obliczeniowe programu AVL.

Na podstawie rzeczywistych wymiarów silnika eksperymentalnego została zbudowana trójwymiarowa siatka komory spalania silnika (rys. 1). Siatka modelowanej komory spalania zmodernizowanego silnika badawczego $1 \mathrm{hc} 102$ składa się prawie z 32000 komórek obliczeniowych. W budowie siatki i w obliczeniach uwzględniono graniczną dwuwarstwową warstwę przyścienną. 
combustion chamber of the $1 \mathrm{hc} 102$ modernized test engine consisted of nearly 32000 computation cells. Two-layered wall boundary layer was considered.

Computations were conducted for the angle range from $180 \mathrm{deg}$ before top dead center (BTDC) to $180 \mathrm{deg}$ after top dead center (ATDC). Calculations included the study of a HCCI engine and conventional compression ignition engine $\mathrm{CI}$. The conventional engine was fueled with a mixture of DME-air equivalence ratio of 0.5 . The HCCI engine fed with a mixture of er $=0.5$ and 0.625 . The modeling of a conventional combustion process was conducted for three of the injection timings: 10, 8 and 6 deg before top dead center for which there was no knock combustion [24-28]. On the basis of the pressure data obtained from modeling indicated pressure pi was calculated. The indicated pressure is one of the parameters determining the performance of a combustion engine. The calculated indicated pressures do not include certain losses both in the combustion process as well as the flow losses and blow-bys. In this paper, to control the ignition timing in HCCI engine a cooled external EGR was used. EGR rate changed from $0 \%$ to $60 \%$. The percentage of the exhaust gases recycled back to the engine intake (\% EGR) was calculated as a percentage of the total intake mass flow rate as follows:

$$
\% \mathrm{EGR}=\frac{\dot{\mathrm{m}}_{\mathrm{EGR}}}{\dot{\mathrm{m}}_{\mathrm{a}}+\dot{\mathrm{m}}_{\mathrm{f}}+\dot{\mathrm{m}}_{\mathrm{EGR}}}
$$

where: $\dot{\mathrm{m}}_{\mathrm{EGR}}$ is mass rate of EGR, $\dot{\mathrm{m}}_{\mathrm{a}}$ is mass rate of air, $\dot{\mathrm{m}}_{\mathrm{f}}$ is mass rate of fuel respectively in $\mathrm{kg} / \mathrm{s}$.

\section{Results of calculation}

\subsection{Modeling combustion without EGR}

Figure 2 shows a comparison history of the DME fuel combustion without EGR between the HCCI engine and conventional CI (compression ignition) engine. Some basic combustion parameters of the combustion process in $\mathrm{HCCI}$ and conventional compression ignition engine are also shown in this figure. $\mathrm{HRR}_{\max }$ is defined as the maximum value of heat release rate in combustion process. The timing of SOI (start of ignition) is defined as that point on the HRR graph at which the rate of heat release rate exceeds $0.5 \mathrm{~J} / \mathrm{deg}$, as shown in Fig. 2 [29]. The BD (burn duration) is defined as the combustion duration, which is the distance between the crank angle of SOI and crank angle corresponding to $20 \%$ of the magnitude of peak of heat release rate on the falling side of the curve [1]. Characteristics show a large difference between the HCCI engine and a conventional engine in the ignition timing, maximum heat release rate, maximum pressure and temperature. In the case of the conventional engine, the ignition occurs near TDC because the ignition timing can be controlled by the fuel injection timing, while, in the case of the HCCI engine, which does not have a mechanism to control combustion, the ignition occurs earlier than in the case of the conventional compression ignition engine.
Obliczenia przeprowadzono w zakresie kąta obrotu wału korbowego od $180^{\circ} \mathrm{OWK}$ przed górnym martwym punktem (przed GMP) do $180^{\circ} \mathrm{OWK}$ po górnym martwym punkcie (po GMP). Obliczenia obejmowały badania zarówno silnika HCCI, jak i konwencjonalnego silnika wysokoprężnego. Konwencjonalny silnik pracował na mieszance DME z powietrzem o współczynniku ekwiwalencji er $=0,5$. Silnik HCCI zasilany był mieszanką o er $=0,5$ i 0,625.

Modelowanie konwencjonalnego procesu spalania przeprowadzono dla trzech kątów wyprzedzenia wtrysku IT: 10, 8 i 6 stopni przed GMP, dla których nie wystąpiło spalanie stukowe [24-28]. Na podstawie przebiegu ciśnień w komorze spalania uzyskanych z modelowania obliczono wartość ciśnienia indykowanego $\mathrm{p}_{\mathrm{i}}$, które jest jednym $\mathrm{z}$ wskaźników charakteryzujących pracę silnika spalinowego pod względem jego osiągów. Obliczone ciśnienie indykowane $\mathrm{z}$ modelowania nie uwzględnia wielu strat zarówno w procesie spalania (niezupełne i niecałkowite), jak i strat przepływowych oraz przedmuchów. W niniejszej pracy do kontroli czasu zapłonu w silniku HCCI wykorzystano chłodzony zewnętrzny EGR. Udział EGR zmieniał się od $0 \%$ do $60 \%$. Zawartość procentowa spalin zawróconych z powrotem do układu dolotowego silnika (\% EGR) została obliczona jako procent całkowitego strumienia masy ładunku doprowadzanego (1), gdzie: $\dot{\mathrm{m}}_{\mathrm{EGR}}$ - strumień masy EGR $[\mathrm{kg} / \mathrm{s}], \dot{\mathrm{m}}_{\mathrm{a}}-$ strumień masy powietrza $[\mathrm{kg} / \mathrm{s}], \dot{\mathrm{m}}_{\mathrm{f}}-$ strumień masy paliwa $[\mathrm{kg} / \mathrm{s}]$.

\section{Wyniki obliczeń}

\subsection{Modelowanie spalania bez EGR}

$\mathrm{Na}$ rysunku 2 przedstawiono porównanie przebiegu spalania paliwa DME bez EGR pomiędzy silnikiem HCCI, a konwencjonalnym silnikiem o zapłonie samoczynnym ZS. Pokazano na nim również kilka podstawowych, analizowanych parametrów procesu spalania w silniku HCCI oraz konwencjonalnym silniku ZS. $\mathrm{HRR}_{\max }$ jest definiowana jako maksymalna wartość szybkości wydzielania ciepła w procesie spalania. Parametr SOI jest to czas początku zapłonu, zdefiniowany jako punkt na wykresie HRR (rys. 2), w którym szybkość wydzielania ciepła przekracza wartość $0,5 \mathrm{~J} /{ }^{\circ} \mathrm{OWK}$ [28]. BD jest definiowany jako czas trwania spalania, który jest odległością pomiędzy kątem obrotu wału korbowego odpowiadającym SOI i kątem odpowiadającym $20 \%$ wartości maksymalnej szybkości wydzielania ciepła $\mathrm{HRR}_{\max }$, odmierzonej po stronie opadania charakterystyki HRR [1].

Przedstawione na rysunku 2 charakterystyki pokazują dużą różnicę pomiędzy silnikiem HCCI, a konwencjonalnym silnikiem ZS, w czasie wystąpienia samozapłonu, maksymalnej szybkości wydzielania ciepła oraz maksymalnych wartości ciśnienia i temperatury w cylindrze. Dla silnika konwencjonalnego ZS, zapłon następuje w pobliżu GMP, ponieważ kąt wyprzedzenia zapłonu może być kontrolowany przez kąt wtrysku paliwa. Dla silnika HCCI zapłon następuję znacznie wcześniej niż w silniku konwencjonalnym o zapłonie samoczynnym, ponieważ nie ma on mechanizmu kontroli procesu spalania. Zgodnie z 
Numerical study of EGR effects on the combustion process parameters...

As shown in the heat release curves, DME in HCCI clearly shows two-stage combustion phenomena, that is, the low-temperature reaction and the high-temperature reaction. The two-stage combustion mechanism is typical of diesel fuel and also occurs with lighter fuels, such as kerosene. In the case of this type of combustion, at 760-880 K, about 5-15 deg C.A. before principal and fast heat release, cold blue flames appear and a preliminary heat release occurs [31]. The results of modeling show that for a conven-

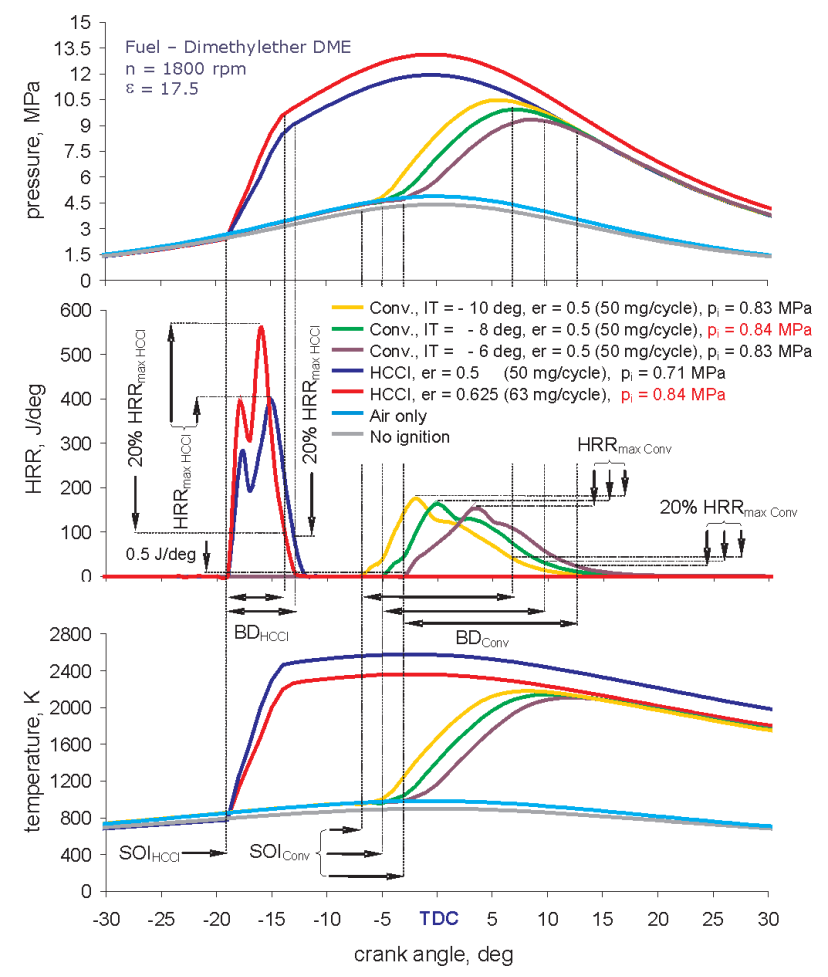

Fig. 2. Comparison of the history of the DME fuel combustion without EGR between HCCI and conventional compression ignition engine CI

Rys. 2. Porównanie przebiegu procesu spalania paliwa DME bez EGR pomiędzy silnikiem HCCI a konwencjonalnym silnikiem o zapłonie samoczynnym

tional engine powered by mixture of er $=0.5$, the most optimum injection timing angle (IT) is an angle equal to $8 \mathrm{deg}$ before TDC. For this injection angle the maximum indicated pressure achieved equals $0.84 \mathrm{MPa}$. In the HCCI engine, with er $=0.5$, the maximum indicated pressure achieved equals $0.71 \mathrm{MPa}$. Obtaining the value of $\mathrm{pi}=$ $0.84 \mathrm{MPa}$ in the HCCI engine was associated with the enrichment of the fuel mixture to a value of er $=0.625$. As a consequence an increase in the mixture equivalence ratio results in a worsening of the engine fuel consumption. Figure 2 and Table 2 show that the combustion process in the HCCI engine compared to a conventional engine is characterized by an earlier ignition (SOI) and shorter burn duration (BD).
Table 2. Selected results of the modeled combustion process without EGR

Tabela 2. Wybrane wyniki modelowania procesu spalania bez EGR

\begin{tabular}{|c|c|c|c|c|c|}
\hline $\begin{array}{c}\text { IT } \\
{[\mathrm{deg}]}\end{array}$ & $\begin{array}{c}\mathrm{er} \\
{[-]}\end{array}$ & $\begin{array}{c}\mathrm{p}_{\mathrm{i}} \\
{[\mathrm{MPa}]}\end{array}$ & $\begin{array}{c}\mathrm{SOI} \\
{[\mathrm{deg}]}\end{array}$ & $\begin{array}{c}\mathrm{BD} \\
{[\mathrm{deg}]}\end{array}$ & $\begin{array}{c}\mathrm{NO} \\
{[\mathrm{ppm}]}\end{array}$ \\
\hline-10 & 0.5 & 0.83 & -7 & 14 & 662 \\
\hline-8 & 0.5 & 0.84 & -5 & 15 & 621 \\
\hline-6 & 0.5 & 0.83 & -3 & 16 & 548 \\
\hline- & 0.5 & 0.71 & -19.5 & 6.5 & 1034 \\
\hline- & 0.625 & 0.84 & -19.5 & 5.5 & 975 \\
\hline
\end{tabular}

krzywymi szybkości wywiązywania ciepła, spalanie paliwa DME wyraźnie wykazuje cechy spalania dwustopniowego, w którym wyróżnić można wpływ niskotemperaturowych i wysokotemperaturowych reakcji na przebieg procesu spalania. Dwustopniowy mechanizm spalania jest typowy dla oleju napędowego, a także dla lżejszych paliw, takich jak np. nafta. $\mathrm{W}$ odniesieniu do tego rodzaju spalania $\mathrm{w}$ temperaturze $760-880 \mathrm{~K}$, około $5-15^{\circ} \mathrm{OWK}$ przed rozpoczęciem zasadniczego, szybkiego procesu wywiązywania się ciepła, powstają tzw. zimne płomienie i pojawia się wstępne wydzielanie ciepła [31].

Uzyskane wyniki modelowania wskazują, że dla silnika konwencjonalnego zasilanego mieszanką o er $=0,5$ najbardziej odpowiednim kątem wyprzedzenia wtrysku jest kąt równy $8^{\circ}$ przed GMP. Dla tego kąta wtrysku osiągnięto maksymalną wysokość ciśnienia indykowanego równą 0,84 MPa. $\mathrm{W}$ silniku HCCI z er = 0,5 maksymalne ciśnienie indykowane było równe $0,71 \mathrm{MPa}$. Uzyskanie w silniku HCCI wartości $\mathrm{p}_{\mathrm{i}}$ $=0,84 \mathrm{MPa}$ wiązało się ze wzbogaceniem mieszanki palnej do wartości er $=0,625$. Wzrost współczynnika ekwiwalencji (er) mieszanki powoduje jednak w konsekwencji pogorszenie zużycia paliwa silnika.

$\mathrm{Z}$ analizy rysunku 2 i tabeli 2 wynika, że proces spalania w silniku HCCI w porównaniu z konwencjonalnym silnikiem charakteryzuje się wcześniejszym zapłonem (SOI) i krótszym czasem spalania (BD).

Silnik HCCI bez EGR charakteryzuje się większą emisją NO w porównaniu do konwencjonalnego silnika ZS (tab. 2 i rys. 3). Niekontrolowane spalanie HCCI charakteryzuje się większą emisją tlenków azotu niż kontrolowane spalanie w silniku ze sterowanym wtryskiem paliwa.

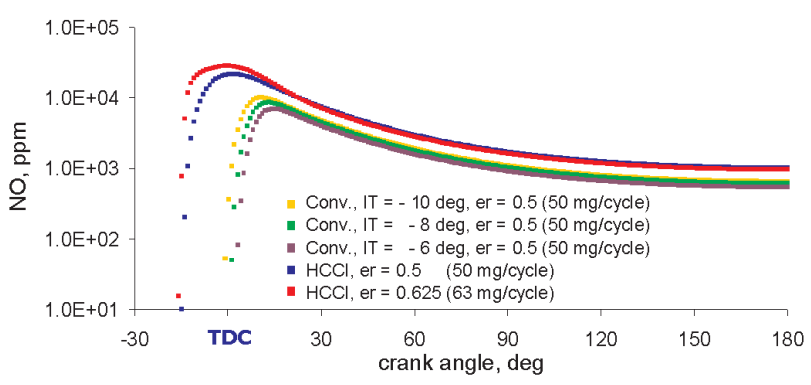

Fig. 3. Nitric oxides emission from conventional CI engine in comparison with the emission from the HCCI engine

Rys. 3. Porównanie emisji tlenku azotu konwencjonalnego silnika ZS z emisja silnika HCCI 
The HCCI engine without EGR, characterized by a higher $\mathrm{NO}_{\mathrm{x}}$ emissions compared to conventional engine CI (Tab. 2 and Fig. 3). Uncontrolled HCCI combustion is characterized by higher emission of the nitric oxides than it is in the case of a controlled combustion in a fuel injected engine.

\subsection{Modeling HCCI combustion with EGR}

EGR is widely used as the main method to depress the $\mathrm{NO}_{\mathrm{x}}$ emission from conventional compression ignition engines. Currently, EGR is also used as the basic method to control the ignition timing and burn rate in the HCCI combustion. The application of EGR on HCCI combustion engine has a number of effects on the combustion process and emissions [1-8]. Firstly, the dilution effect - the introduction of EGR leads to a substantial reduction of the oxygen concentration in the engine cylinder. Secondly, the heat capacity effect - the total heat capacity of the mixture of EGR gas, air, and fuel will be higher owing to the higher heat capacity of carbon dioxide and water vapor in the EGR gas. Thirdly, the chemical effect - the combustion products in the EGR will take part in the chemical reactions and this leads to moderate effects on the reaction rates. All this may lead to delaying of the time of ignition and increasing the duration of combustion.

In this part, through the modeling, the effects of cooled, external EGR on the HCCI combustion using DME fuel were evaluated. The fuel delivery rate was fixed at 50 $\mathrm{mg} / \mathrm{cycle}$ for all operating conditions. The intake charge

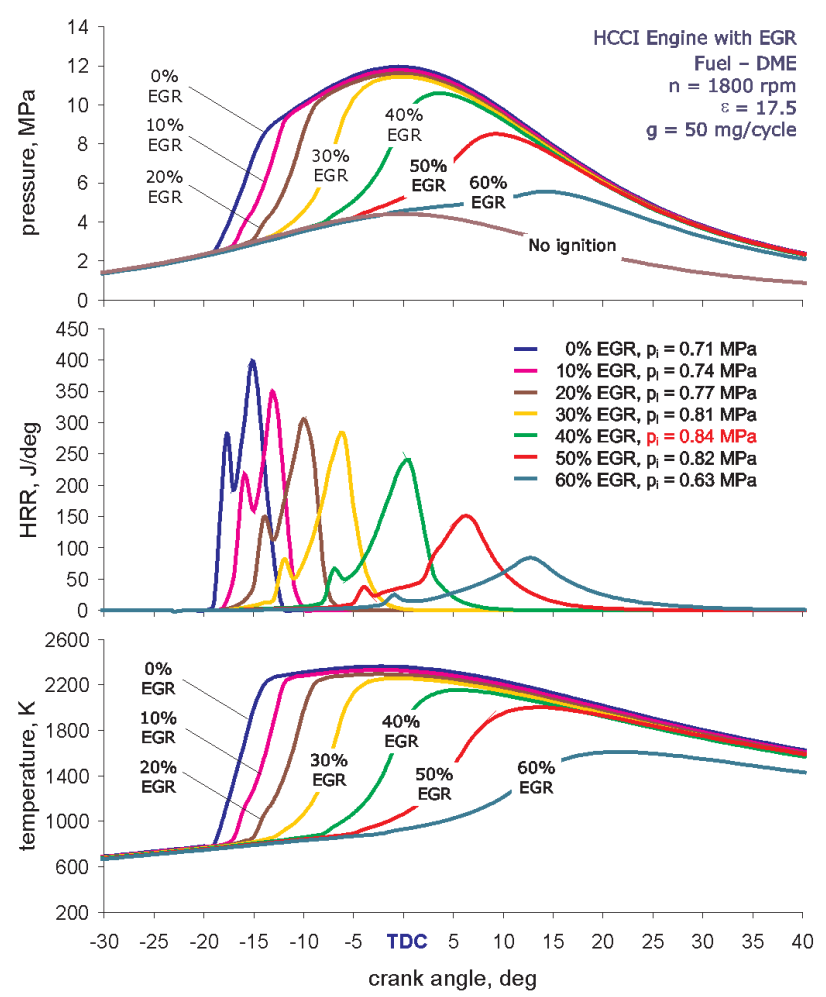

Fig. 4. The effect of cooled EGR rate on the gas pressure, gas temperature and heat release rate

Rys. 4. Wpływ chłodzonego EGR na ciśnienie i temperature gazu oraz szybkość wydzielania ciepła

\subsection{Modelowanie spalania HCCI z EGR}

EGR jest powszechnie stosowaną metodą skutecznie ograniczającą stężenie NO w spalinach silników konwencjonalnych o zapłonie samoczynnym. Obecnie EGR jest również wykorzystywany jako podstawowa metoda kontroli chwili zapłonu i czasu trwania spalania w silniku z systemem HCCI. Zastosowanie EGR w silniku z HCCI ma znaczący wpływ na parametry procesu spalania i emisję szkodliwych składników spalin [1-8]. Po pierwsze zastosowanie EGR wywołuje efekt rozcieńczenia, które prowadzi do znacznego zmniejszenie stężenia tlenu w cylindrze silnika. Po drugie wpływa na całkowitą pojemność ładunku. Pojemność cieplna mieszaniny EGR, powietrza i paliwa będzie większa z powodu większej pojemności cieplnej dwutlenku węgla i pary wodnej z EGR. Trzeci rezultat to efekt chemiczny uwzględniający produkty spalania ze spalin EGR w reakcjach chemicznych procesu spalania i ograniczający szybkość przebiegu tych reakcji. To wszystko może doprowadzić do opóźnienia zapłonu i wydłużenia czasu trwania spalania.

W tej części pracy, za pomocą modelowania, oceniano wpływ chłodnego, zewnętrznego EGR na spalanie paliwa DME w systemie HCCI. Dla wszystkich analiz ustalono stałą dawkę paliwa doprowadzanego do cylindra równą 50 mg/cykl. Temperatura ładunku dolotowego (temperatura mieszaniny EGR, świeżego powietrza i paliwa) została ustalona na poziomie $340 \mathrm{~K}$.

Na rysunku 4 przedstawiono wpływ chłodzonego EGR na ciśnienie gazu, przebieg wydzielania ciepła i temperaturę gazu podczas spalania paliwa DME w systemie HCCI. Wraz ze wzrostem udziału EGR opóźnia się początek spalania, spada maksymalne ciśnienie i temperatura i zmniejsza się również wartość szczytowa szybkości wydzielania ciepła. Gdy udział EGR wzrasta do $60 \%$, proces spalania HCCI jest nieprawidłowy i bliski granicy spalania niecałkowitego. Wartość ciśnienia indykowanego $\mathrm{p}_{\mathrm{i}}=0,84 \mathrm{MPa}$ uzyskano przy $\mathrm{EGR}=40 \%$.

Na rysunku 5 przedstawiono wpływ chłodzonego EGR na podstawowe parametry spalania HCCI, w tym chwilę zapłonu i czas trwania spalania. Jak widać, wraz z wprowadzeniem chłodzonego EGR opóźnia się chwila zapłonu i początek pojawienia się tzw. zimnych płomieni. Gdy temperatura doprowadzanego ładunku była utrzymywana na stałym poziomie, wpływ EGR na spalanie HCCI wynikał głównie z trzech powodów. Pierwszy to wzrost pojemności cieplnej całkowitego ładunku w wyniku doprowadzenia coraz większych ilości EGR, o wysokiej pojemności cieplnej. W rezultacie w porównaniu do sytuacji bez EGR, podczas suwu sprężania maleje szybkość przyrostu ciśnienia. Drugi - skutek rozcieńczania ładunku i zmniejszenie udziału czystego paliwa. Ponadto produkty spalania obecne w EGR, $\mathrm{tj}$. $\mathrm{CO}, \mathrm{CO}_{2}, \mathrm{NO}, \mathrm{H}_{2} \mathrm{O}$, powodują, że stężenie końcowych produktów zwiększa się, zostają wstrzymane reakcje utleniania paliwa i zaczynają dominować reakcje odwrotne. Połączenie wszystkich tych efektów powoduje, że początek wystąpienia zimnych płomieni, a tym samym chwila zapłonu, zostają przesunięte. W związku z tym całkowity czas spalania HCCI ulega wydłużeniu. 
temperature (temperature of mixture of EGR gas, fresh air, and fuel) was fixed at $340 \mathrm{~K}$.

Figure 4 shows the effect of cooled EGR rate on the gas pressure, heat release traces and gas temperature of HCCI combustion using DME fuel. With the increasing EGR rate, the start of combustion delay, the maximum gas pressure and temperature decrease, and the peak value of heat release rate also decreases. When the EGR rate increases to $60 \%$, the HCCI combustion is close to the incomplete combustion limit. The indicated pressure $\mathrm{p}_{\mathrm{i}}=0.84 \mathrm{MPa}$ was achieved at $\mathrm{EGR}=40 \%$. Figure 5 shows the effect of cooled EGR rates on the basic combustion parameters including the ignition timing and the burn duration of HCCI combustion. As can be seen, the onset of cool flame slightly delayed with the introduction of cooled EGR. When the intake charge temperature was kept constant, the effects of EGR on HCCI combustion were mainly due to three reasons. Firstly, the heat capacity of mixtures increased with the increase of EGR rate. As a result, the pressure rising rate during the compression stroke decreased compared to without EGR or with a lower EGR. Secondly, the pure fuel concentration reduced for the dilution effect. Moreover, the products including $\mathrm{CO}, \mathrm{CO}_{2}, \mathrm{NO}, \mathrm{H}_{2} \mathrm{O}$ presence in the EGR made the concentrations of the final products increase. This prevented the oxidation reaction and promoted the reverse reactions. Integrating all these effects, the start of cool flame postponed. Accordingly, the combustion timing of overall HCCI combustion also delayed.

According to chemical kinetics, the most important chain-branching mechanism occurs at high temperature due to the following reaction:

$$
\mathrm{H}+\mathrm{O}_{2}=\mathrm{O}+\mathrm{OH}
$$

That means oxygen concentrations at high temperature play an important role in the reaction rate and the reaction duration. The increasing of EGR rate leads to a notable reduction of oxygen concentration in the cylinder. As a result, the burn duration of DME fuel increases with the increase of the EGR rate.

Figure 6 shows the $\mathrm{NO}_{\mathrm{x}}$ emissions for DME fuel versus EGR rate at a fixed DME fuel consumption rate. Increase of EGR rate leads to reduced emissions of $\mathrm{NO}_{\mathrm{x}}$. The slight decrease in the concentration of nitric oxides was obtained for up to $30 \%$ EGR. A significant decrease in the concentration of $\mathrm{NO}_{x}$ was above $30 \%$ EGR. The reduction of $\mathrm{O}_{2}$ concentration in the chamber and the decrease in the combustion temperature associated with addition of EGR is the main cause of lower levels of $\mathrm{NO}_{x}$.

For the same fuel consumption $(50 \mathrm{mg} /$ cycle) and performance $\left(\mathrm{p}_{\mathrm{i}}=0.84 \mathrm{MPa}\right)$, the HCCI engine with a $40 \%$ EGR compared to a

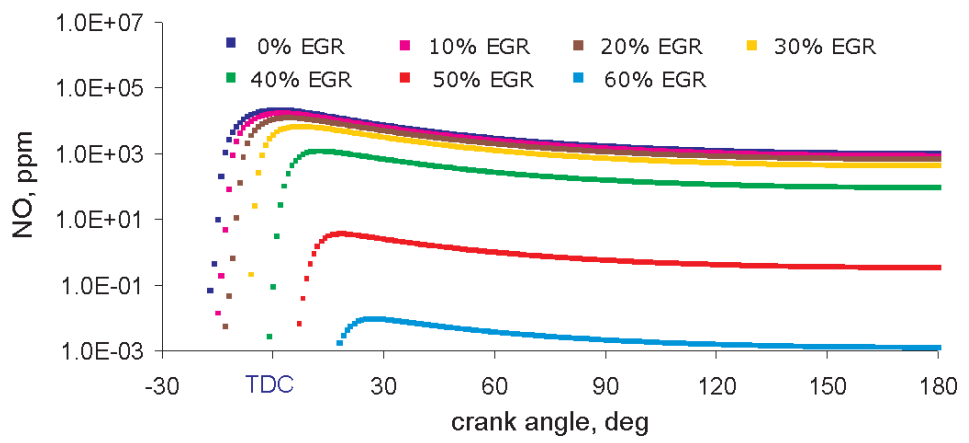

Fig. 6. Effect of cooled EGR rate on the nitric oxides emission of the model HCCI engine

Rys. 6. Wpływ chłodnego EGR na emisję tlenku azotu modelu silnika HCCI 
conventional $\mathrm{CI}$ engine has achieved a much lower $\mathrm{NO}_{x}$ emissions. $\mathrm{NO}_{\mathrm{x}}$ concentration was reduced from $622 \mathrm{ppm}$ for the conventional engine to $96 \mathrm{ppm}$ for the HCCI engine (Fig. 7 and 8).

\section{Conclusions}

This paper discussed the effect of EGR rate on HCCI combustion parameters and $\mathrm{NO}_{\mathrm{x}}$ emissions. Based on these discussions, some conclusions may be drawn:

- The control of the process of HCCI combustion in the engine is possible with the use of cooled external EGR.

- Too early an ignition in uncontrolled HCCI combustion causes a reduction in engine performance parameters $\left(\mathrm{p}_{\mathrm{i}}\right)$ compared to the controlled ignition in a conventional compression engine.

- Cooled external EGR can delay the start of ignition (SOI) effectively, which is very useful for high cetane fuel (DME) HCCI because these fuels can easily self-ignite, making the SOI earlier.

- Increasing of the EGR rate in HCCI engine leads to a prolongation of the burn duration (BD).

- Delayed ignition in the HCCI engine through EGR, can provide similar performance compared to conventional CI engine (pi) and at the same time provide a significant reduction in the $\mathrm{NO}_{\mathrm{x}}$ emissions.

- For the same fuel consumption and performance, HCCI engine with a $40 \%$ EGR compared to a conventional CI engine has achieved a much lower NO emissions.

\section{Acknowledgements}

The author would like to express their gratitude to AVL LIST GmbH for providing a AVL Fire software under the University Partnership Program.

Paper reviewed/Artykut recenzowany

\section{Nomenclature/Skróty i oznaczenia}

AVL AVL List GmbH

HCCI homogenous charge compression ignition/zapłon samoczynny mieszanki jednorodnej

EGR exhaust gas recirculation/recyrkulacja spalin

DME dimethylether $\mathrm{CH}_{3} \mathrm{OCH}_{3}$ /eter dimetylowy

CI compression ignition engine/zapłon samoczynny

SOI start of the ignition/chwila poczatku zapłonu

BD burn duration/czas trwania spalania

IT injection timing/kat wyprzedzenia wtrysku

HRR heat release rate/szybkość wydzielania ciepła

NO nitric oxide/tlenek azotu

TDC top dead center/górny martwy punkt

$\mathrm{p}_{\mathrm{i}} \quad$ indicated pressure/ciśnienie indykowane

er equivalence ratio/wspótczynnik ekwiwalencji

n engine speed/prędkość obrotowa

$\varepsilon \quad$ compression ratio/stopień sprężania

g fuel delivery rate per cycle/dawka paliwa na cykl
NO $[\mathrm{ppm}] \quad$ Conventional engine with $\mathrm{IT}=-8 \mathrm{deg}$

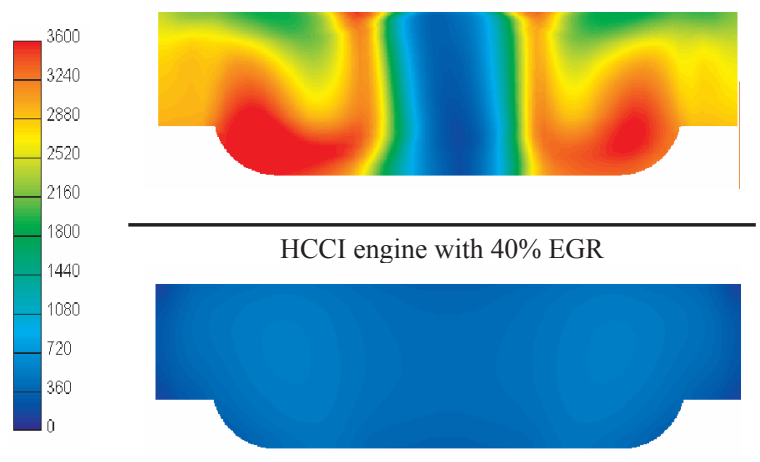

Fig. 7. $\mathrm{NO}_{\mathrm{x}}$ concentration in the combustion chamber of a conventional engine and the HCCI engine with EGR at 40 deg after TDC

Rys. 7. Stężenie $N O_{x}$ w komorze spalania konwencjonalnego silnika i silnika HCCI z EGR przy $40^{\circ} \mathrm{OWK}$ po GMP

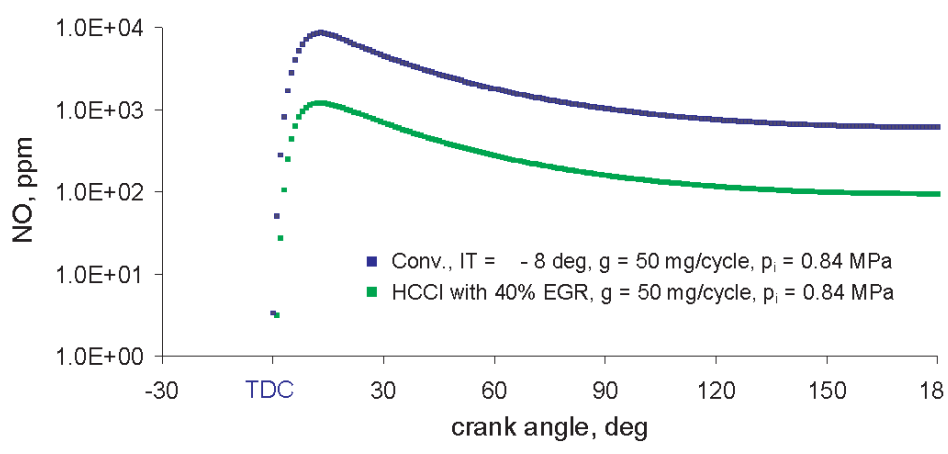

Fig. 8. $\mathrm{NO}_{\mathrm{x}}$ emission of a conventional CI engine in comparison with the emission of the HCCI engine with EGR

Rys. 8. Porównanie emisji NO konwencjonalnego silnika ZS z emisja silnika HCCI z EGR

podstawie przeprowadzonej analizy można wysunąć następujące wnioski:

- Kontrola procesu spalania w silniku HCCI jest możliwa z wykorzystaniem chłodzonego zewnętrznego EGR.

- Zbyt wczesny zapłon w niekontrolowanym spalaniu typu HCCI jest przyczyną obniżenia parametrów użytkowych silnika $\left(\mathrm{p}_{\mathrm{i}}\right)$ w porównaniu do kontrolowanego zapłonu w konwencjonalnym silniku wysokoprężnym.

- Chłodzony zewnętrzny EGR może skutecznie opóźnić rozpoczęcie zapłonu (SOI) w silniku HCCI, co jest bardzo przydatne dla paliw o wysokiej liczbie cetanowej, takich jak DME, ponieważ paliwa te mogą łatwo ulegać samozapłonowi, przyspieszając początek spalania.

- Zwiększenie udziału EGR w silniku HCCI prowadzi do wydłużenia czasu trwania spalania (BD).

- Opóźniony zapłon w silniku HCCI przy użyciu EGR może umożliwić uzyskanie zbliżonych osiągów $\left(\mathrm{p}_{\mathrm{i}}\right)$ w porównaniu do konwencjonalnego silnika ZS i jednocześnie zapewnia znaczące zmniejszenie emisji NO.

- Przy takim samym zużyciu paliwa i takich samych osiągach, silnik HCCI z 40\% EGR w porównaniu do konwencjonalnego silnika ZS uzyskał znacznie niższy poziom emisji NO. 


\section{Bibliography/Literatura}

[1] Lu X.C., Chen W., Huang Z.: A fundamental study on the control of the HCCI combustion and emissions by fuel design concept combined with controllable EGR. Part 1. The basic characteristics of HCCI combustion, p.1074-1083, Fuel 84, 2005.

[2] Lu X.C., Chen W., Huang Z.: A fundamental study on the control of the HCCI combustion and emissions by fuel design concept combined with controllable EGR. Part 2. Effect of operating conditions and EGR on HCCI combustion, p. 10841092, Fuel 84, 2005

[3] Kim D.S., Lee Ch.S.: Improved emission characteristics of HCCI engine by various premixed fuels and cooled EGR. p. 695-04, Fuel 85, 2006.

[4] Shi L., Cui Y., Deng K., Peng H., Chen Y.: Study of low emission homogeneous charge compression ignition (HCCI) engine using combined internal and external exhaust gas recirculation (EGR), p. 2665-2676, Energy 31, 2006.

[5] Chen R., Milovanovic N.: A computational study into the effect of exhaust gas recycling on homogeneous charge compression ignition combustion in internal combustion engines fuelled with methane. International Journal of Thermal Sciences 41, p. 805-813, 2002.

[6] Sjöberg M., Dec J.E.: Effects of EGR and its constituents on HCCI autoignition of ethanol. Proceedings of the Combustion Institute 33, p. 3031-3038, 2011.

[7] Qian Z., Lu X.: Characteristics of HCCI engine operation for additives, EGR, and intake charge temperature while using iso-octane as a fuel. Journal of Zhejiang University Science A, 2006.

[8] Chen G., Iida N., Huang Z.: Numerical study of EGR effects on reducing the pressure rise rate of HCCI engine combustion. Front. Energy Power Eng., p. 376-385, China 2010, 4(3).

[9] Kim H.J., Suh H.K., Lee C.S.: A study on an application of a hybrid break-up model for dimethyl ether atomization in a common-rail injection system. Proc. IMechE Vol. 223 Part D: J. Automobile Engineering, p. 1351-1359, 2009

[10] Jamrozik A., Kociszewski A., Sosnowski M., Tutak W.: Simulation of combustion in SI engine with prechamber. CADMD'2006, CAD in Machinery Design Implementation and Educational Problems, Polyana, Ukraine, p. 66-69, May 2006.

[11] Jamrozik A., Tutak W., Kociszewski A., Sosnowski M.: Numerical Analysis of Influence of Prechamber Geometry in IC Engine with Two Stage Combustion System on Engine Work Cycle Parameters. Journal of KONES. Vol 13, No 2, pp. 133 142, Warsaw 2006.

[12] Tutak W., Jamrozik A., Kociszewski A., Sosnowski M.: Numerical analysis of initial swirl profile influence on modeled piston engine work cycle parameters. Combustion Engines/ Silniki Spalinowe, 2007-SC2, p. 401-407, 2007.

[13] Kociszewski A., Jamrozik A., Sosnowski M., Tutak W.: Simulation of combustion in multi spark plug engine in KIVA-3V. Combustion Engines/Silniki Spalinowe. 2007-SC2, p. 212 219, 2007.

[14] Kociszewski A.: Numerical analysis of spark plugs number influence on selected parameters of combustion in piston engine. Combustion Engines/Silniki Spalinowe, p. 50-55, No. $1 / 2008$ (132).

[15] Kociszewski A.: Three-dimensional modelling and experiment on combustion in multipoint spark ignition engine. MEMSTECH 2009, p.20-23 Lviv-Polyana, Ukraine 22 - 24 April 2009 .
[16] AVL Fire version 2009, ICE Physics \& Chemistry, Combustion, Emission, Spray, Wallfilm. AVL LIST GmbH, 2009.

[17] Jamrozik A., Tutak W.: Modelling of combustion process in the gas test engine. MEMSTECH 2010. p. 14-17, Lviv - Polyana 2010.

[18] Tutak W., Jamrozik A.: Numerical analysis of some parameters of gas engine. Commission of Motorization and Power Industry in Agriculture, Volume X, p. 491-502, Polish Academy of Science Branch in Lublin. Lublin 2010.

[19] Tutak W., Jamrozik A.: Modelling of the thermal cycle of gas engine using AVL Fire Software. COMBUSTION ENGINES/ Silniki Spalinowe, p. 105-113, No. 2/2010 (141).

[20] Sosnowski M., Tutak W., Jamrozik A., Kociszewski A.: Modelowanie obiegu cieplnego tłokowego silnika spalinowego o zapłonie iskrowym z uwzględnieniem recyrkulacji spalin. Edukacja Techniczna i Informatyczna V, s. 29-38, Częstochowa 2010.

[21] Tutak W., Jamrozik A., Kociszewski A.: Improved emission characteristics of SI test engine by EGR. MEMSTECH 2011. p. 101-103, Lviv - Polyana 2011.

[22] Tutak W., Jamrozik A., Kociszewski A.: Three dimensional modelling of combustion process In SI engine with Exhaust Gas Recirculation. 10th Jubilee International Conference on Heat Engines and Environmental Protection. p. 203-208, ref. 27. Hungary May 2011.

[23] Cupiał K., Tutak W., Jamrozik A., Kociszewski A.: The accuracy of modelling of the thermal cycle of a self-ignition engine. Combustion Engines/Silniki Spalinowe, p. 37-48, No. 1/2011 (144).

[24] Naber J.D., Szwaja S.: Statistical approach to characterize combustion knock in the hydrogen fuelled SI engine, Journal of Kones 2007, European KONES2007 Congress, Warsaw, Poland, 2007.

[25] Szwaja S.: Hydrogen rich gases combustion in the IC engine, Journal of Kones - Powertrain and Transport, Warsaw 2009, Vol.16, No.4, 447-455, 2009.

[26] Szwaja S.: Time-frequency representation of combustion knock in an internal combustion engine, Combustion Engines, p. 306-315, PTNSS-2009-SC-132.

[27] Szwaja S.: Combustion Knock - Heat Release Rate Correlation of a Hydrogen Fueled IC Engine Work Cycles, 9th International Conference on Heat Engines and Environmental Protection. Proceedings. Balatonfured, Hungary, 2009.

[28] Cupiał K., Szwaja S.: Producer gas combustion in the internal combustion engine, Combustion Engines, p. 27-32, No. $2 / 2010$.

[29] Inagaki K., Fuyuto T., Nishikawa K., Nakakita.: Combustion system with premixture - controlled compression ignition. R\&D Review of Toyota, CRDL Vol. 41, p. 35-46, No. 3, 2006.

[30] Ishida M., Jung S., Ukei H., Sakaguchi D.: Combustion of premixed DME and natural gas in a HCCI engine. Combustion Engines/Silniki Spalinowe, p. 20-29, No. 2/2005 (121).

[31] Hunicz J., Niewczas A., Kordos P.: A research into a gasoline HCCI engine. Combustion Engines/Silniki Spalinowe, p. 3-13, No. $1 / 2010$ (140).

Arkadiusz Jamrozik, DEng. - doctor in the Faculty of Mechanical Engineering and Computer Science of Częstochowa University of Technology.

Dr inż. Arkadiusz Jamrozik - adiunkt na Wydziale Inżynierii Mechanicznej i Informatyki Politechniki Częstochowskiej.

e-mail:jamrozik@imtits.pcz.czest.pl 